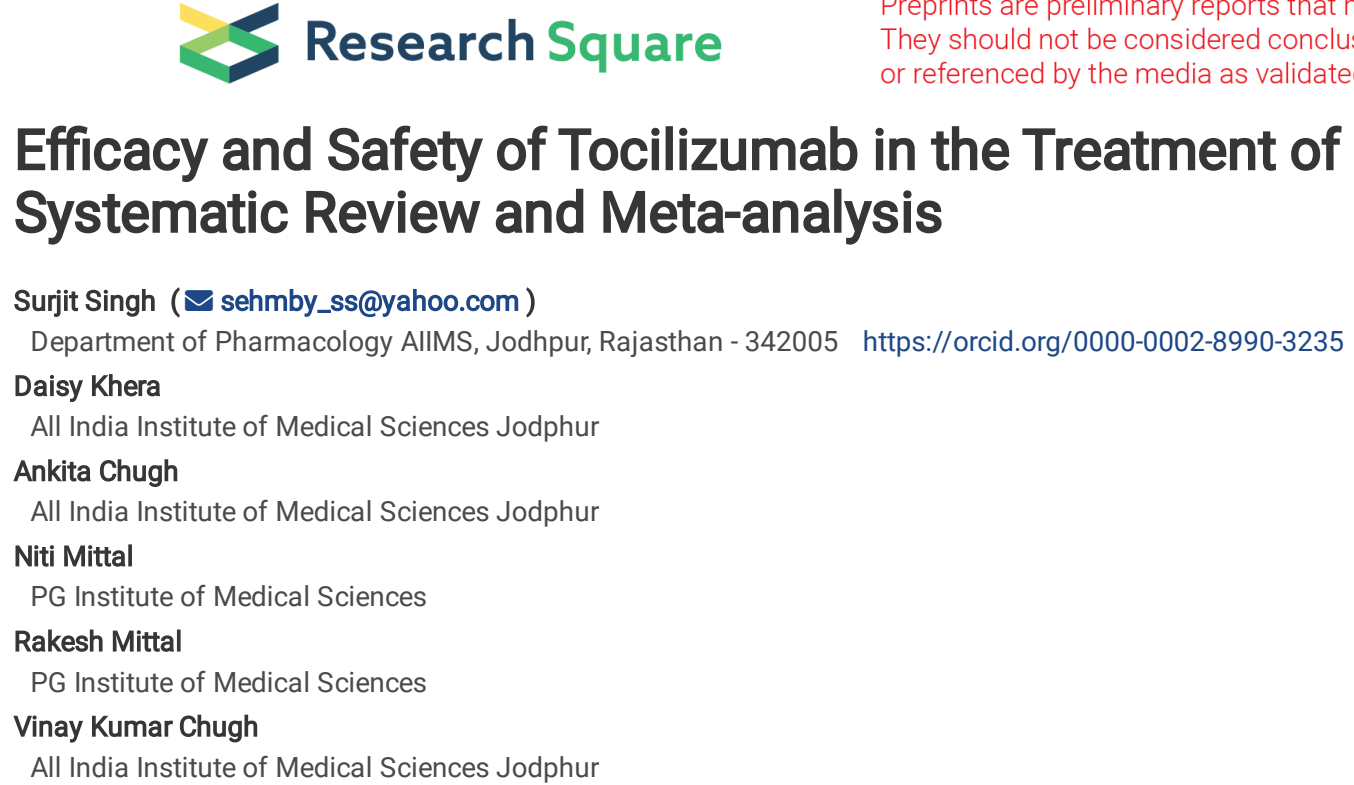

Surjit Singh ( $\square$ sehmby_ss@yahoo.com )

Department of Pharmacology AllMS, Jodhpur, Rajasthan - 342005 https://orcid.org/0000-0002-8990-3235

Daisy Khera

All India Institute of Medical Sciences Jodphur

Ankita Chugh

All India Institute of Medical Sciences Jodphur

Niti Mittal

PG Institute of Medical Sciences

Rakesh Mittal

PG Institute of Medical Sciences

Vinay Kumar Chugh

All India Institute of Medical Sciences Jodphur

\title{
Efficacy and Safety of Tocilizumab in the Treatment of SARS-CoV-2: A Systematic Review and Meta-analysis
}

\section{Research}

Keywords: Tocilizumab, COVID-19, SARS-CoV-2

Posted Date: August 25th, 2020

DOI: https://doi.org/10.21203/rs.3.rs-59511/v1

License: (c) (1) This work is licensed under a Creative Commons Attribution 4.0 International License. Read Full License 


\section{Abstract}

Background: Cytokine storm is the main cause of mortality in COVID-19. Tocilizumab, an IL-6 inhibitor, is being tested for its therapeutic potential in this condition. To evaluate the efficacy and safety of Tocilizumab in comparison to Standard therapy in the treatment of COVID-19 in adult patients.

Methods: Using Medline (via PubMed), The Cochrane Central Register of Controlled Trials, preprint server (medRxiv) and clinicaltrials.gov, a final search was conducted on $26^{\text {th }}$ June 2020. All types of clinical studies (prospective or retrospective cohort studies, observational case-control studies, clinical trials) aiming to evaluate the role of Tocilizumab in the treatment of patients with COVID-19 were considered eligible for this systematic review. Tocilizumab was considered as the intervention group and standard of care or drugs other than tocilizumab as control group. Meta-analysis was performed by Cochrane review manager 5 (RevMan) version 5.3. For quality assessment, ROBINS-I (The Risk Of Bias In Non-randomised studies - of Interventions) assessment tool for observational studies was used. The overall quality of evidence for each of the outcomes was assessed using the GRADE Pro GDT.

Results: Out of 362 records identified, 13 studies were included in qualitative and quantitative analysis. Tocilizumab treatment was associated with $46 \%$ decrease in probability of mortality rate [Adjusted HR $=0.54(95 \% \mathrm{Cl}=0.44-0.68), p<0.00001 ; 12=74 \%$ ] and $66 \%$ odds decrease in progression of disease [OR $=$ $\left.0.34(95 \% \mathrm{Cl}=0.21-0.55), \mathrm{p}<0.0001 ; \mathrm{I}^{2}=76 \%\right]$ compared to control. However, there was no difference in hospital discharge [OR $=1.35(95 \% \mathrm{Cl}=0.84-2.18)$, $\left.p=0.22 ;\left.\right|^{2}=22 \%\right]$ and clinical improvement [OR $=1.02(95 \% \mathrm{Cl}=0.61-1.69), p=0.95 ; 12=84 \%$ ] with tocilizumab. There was statistically significant increase in risk of secondary bacteraemia $[\mathrm{OR}=2.75(95 \% \mathrm{Cl}=1.86-4.06), \mathrm{p}<0.00001]$ and superinfections $[\mathrm{OR}=2.93(95 \% \mathrm{Cl}=1.92-4.46), \mathrm{p}<0.00001]$.

Conclusions: With current evidence on efficacy and safety of tocilizumab, we recommend use of tocilizumab treatment for moderate to severe COVID-19 patients caused by SARS-CoV-2, along with caution for superinfections.

Systematic review registration: PROSPERO registration number: CRD42020189517

\section{Background}

In December 2019, a novel coronavirus disease (COVID-19), caused by infection with SARS-CoV-2, has caused pandemic and was main cause of mortality all over the world. Increased proinflammatory cytokines was pathognomic finding in first death reported from severe SARS-CoV-2 infection.[1] Excessive immune response to infection with the SARS-CoV-2 virus has been incriminated in the respiratory distress and multiorgan failure that is seen in some patients - the socalled "cytokine storm." Previous studies of the cytokine storm associated with other coronavirus (SARS-CoV- 1 and MERS) and influenza virus infections have shown high levels of interleukin (IL)- 6 and other cytokines. A large population of critically ill patients infected with COVID-19 develop cytokine storm mediated by overproduction of proinflammatory cytokines.[2, 3]

It is observed that excess cytokines secretion by pathogenic T-cells and monocytes may evoke a rapid inflammatory response. Flow cytometric profiles of COVID-19 patients have revealed increased IL-6, IL-17, GM-CSF, IFN-y and other inflammatory cytokines in COVID-19 patients with severe disease, whereas no significant increase in TNF-a secretion from CD4 ${ }^{+}$T cells of COVID-19 patients has been observed.[1, 4] So, it is believed that increased IL-6 and IL-17 have led to inflammatory storm or cytokine storm, resulting in impairment of alveolar-capillary blood-gas exchange and hampering oxygen diffusion. Increased TH17 as well as increase cytokine response, especially IL-6 and IL-17 ultimately causes thromboembolic phenomenon leading to cardiac arrest, pulmonary fibrosis and multi-organ failure. Therefore, IL-6 have been implicated to be a major contributor to the cytokine storm, and interfering of IL- 6 might be a potential therapeutic strategy for severe and critical COVID-19 patients. IL- 6 can be used to evaluate the severity of the infection and predict the prognosis.[5]

Patients suffering from cytokine storm progress to, multiple organ failure, cardiovascular complications, happy hypoxia, eventually leading to death. Therefore, early identification, treatment, and prevention of cytokine storm in COVID-19 is of crucial importance for the patients in order to reduce mortality due to this highly infectious disease. Tocilizumab have previously been used to circumvent the cytokine storm induced by chimeric antigen receptor T-cell therapy for non-Hodgkin lymphoma.[6] Tocilizumab (TCZ), a monoclonal antibody against interleukin-6 (IL-6), has emerged as an alternative treatment for COVID-19 patients with a risk of cytokine storm.

Various observational studies have been done, which have shown efficacy of Tocilizumab in reducing mortality rate in COVID-19 patients.[7, 8] However, few have shown no efficacy[9,10] or conflicting results.[11] Randomized controlled clinical trials to assess the benefit-risk ratio of tocilizumab in COVID-19 patients are still lacking. This review was planned with an objective to assess the efficacy and safety of tocillizumab in the treatment of adult COVID-19 patients compared to standard of care.

\section{Methods}

\section{Protocol and registration}

The present systematic review methodology was based upon the PRISMA (Preferred Reporting Items for Systematic Reviews and Meta-Analyses) statement and guidelines of the Cochrane Handbook for Systematic Reviews of Interventions. The protocol was registered with the PROSPERO (International Prospective Register of Systematic Reviews) database with protocol number as CRD42020189517.

\section{Criteria for study inclusion}

In current review, prospective or retrospective cohort studies, randomized or non-randomized clinical trials evaluating the role of tocilizumab compared to standard of care or other drugs in the treatment of COVID-19 patients were included. Case reports or case series were excluded. In addition, the in-vitro studies, expert opinions and literature review articles were excluded. 
We conducted one preliminary literature search on $4^{\text {th }}$ June, 2020 to identify all the relevant articles in published, non-published and pre-print domains. In view of continually evolving literature for SARS-CoV-2, an additional literature search was undertaken on $26^{\text {th }}$ June, 2020 to extract any pertinent published articles which was further updated in the existing searches.

Electronic search was conducted using PubMed, The Cochrane Central Register of Controlled Trials, preprint server (medRxiv) and international clinical trial register (clinicaltrials.gov) for all relevant articles. Bibliographic searching was done to manually identify any more studies (not indexed in the above databases) from reference lists of relevant publications selected by electronic searching. No language or publication status restriction was applied. Search strategy using the following search terms and their associated medical subject headings was developed: 'SARS-CoV 2', 'COVID-19', 'Toiclizumab', 'COVID', 'novel coronavirus'.

The titles and abstracts retrieved by electronic searching were assessed by two independent researchers (NM and SS) for potential eligibility and duplicates removed. Full text articles of potentially eligible studies were obtained for further quality assessment by two researchers (NM and SS) independently with disagreement if any, resolved by consensus with a third review author (DK).

\section{Data extraction}

Data extraction was done using a pre-tested structured data extraction form, which included items such as general study information in addition to study design, study interventions and regimens, number of subjects, study population characteristics, efficacy and safety outcomes.

\section{Study outcomes}

The primary outcomes included in our review were mortality (defined as deaths in each group) and virological cure (negative nasopharyngeal swabs for SARSCoV-2 RNA by RT-PCR). The secondary outcomes assessed were clinical improvement, discharge from hospital, progression of disease (defined as ICU admission, intubation, severe illness or CT progression). Safety outcomes included adverse events like superimposed bacterial infection or pneumonia.

\section{Quality assessment of studies}

Two independent reviewers (DK and AC) assessed the quality of included studies in accordance with Cochrane Collaboration risk of bias assessment tool ROBINS-I [12] (The Risk Of Bias In Non-randomized studies of Interventions) for observational studies. In ROBINS-I, studies were assessed for bias as a result of confounding, selection of participants, classification and deviation from intended interventions, missing data, outcome measurement and selective reporting of results and were assessed as Critical, Serious, Moderate, Low, No information. Robvis (visualization tool)[13] was used for synthesis of plots for risk of bias.[13]

For assessment of publication bias, funnel plot was generated along with Egger's regression test.

\section{Data synthesis and summary measures}

Dichotomous data were summarized as odd ratios (OR) and adjusted hazard ratios (HR) with 95\% confidence intervals (Cl) wherever applicable. Review Manager 5 (RevMan) Version 5.3. (Copenhagen: The Nordic Cochrane Centre, The Cochrane Collaboration, 2014) was used for all the analyses.[14] Heterogeneity was assessed using $I^{2}$ with values of 25,50 , and $75 \%$ indicating low, medium, and large heterogeneity, respectively [15, 16]. For pre-decided significant heterogeneity as $\mathrm{I}^{2}>50 \%$, sensitivity analysis was done to decrease the heterogeneity less than $50 \%$ or heterogeneity was explained wherever possible. The results of fixed effect model presented as applying random effect model for increased heterogeneity can underestimate the overall effect estimate, by awarding more weight to smaller studies $[15,17]$. The generic inverse variance approach, giving more weight to studies with more precise results, was applied. $P$ value $<0.05$ was considered significant.

\section{Assessment of Quality of Evidence - GRADE Pro analysis}

The overall quality of evidence for each of the outcomes was assessed using GRADE pro GDT (guideline development tool) software based on the principles of Grades of Recommendations, Assessment, Development and Evaluations (GRADE).[18] Study design, risk of bias, directness of evidence, consistency and precision of results, risk of publication bias, magnitude of the effect, dose-response gradient, and influence of residual plausible confounding were assessed for grading the overall quality of evidence for individual outcomes. Optimal information size (OIS) was calculated to be 188 patients in each group. Final overall GRADE may be high, moderate, low or very low. The online version of GRADE pro GDT software was accessed from the site: https://gradepro.org/. [19]

\section{Results}

\section{Study selection}

The study selection and exclusion process has been documented using the PRISMA flow diagram (Figure 1). Out of total 362 records screened, 13 observational studies [7-11, 20-27] were included in qualitative (systematic) review as well as in quantitative analysis. Non-comparative intervention studies $(\mathrm{n}=10)$ were not included in meta-analysis.

\section{Study characteristics}


Study characteristics and outcomes data reported in various observational studies included in this systematic review are included in Table 1. Studies done by Garcia et al[22], Kewan et al[9], Klopfenstein et al[23], Quartuccio et al[24], Ramaswamy et al[10], Sanz et al[11] and Wadud et al[27] had significantly more severe disease patients (higher level of inflammation, systemic disease and organ damage) in tocilizumab group that can affect the primary outcomes like mortality, whereas all other studies[7, 8, 20,21, 25, 26] had similar disease severity in both treatment groups. Four studies [8, 20-22] were done in mild to moderate disease whereas nine studies[7, 9-11, 23-27] were done in moderate to severe disease group of patients (Table 1).

\section{Risk of bias (ROB) within the studies}

The overall risk of bias was assessed as moderate except for three studies, Campochiaro et al[20] has been assessed as low risk of bias and Klopfenstein et al[23] and Quartuccio et al[24] evaluated as having serious risk of bias. Overall ROB is similar to bias due to confounding in individual studies. Andrews et al[7], Somers et al[26] and Quartuccio et al[24] had moderate bias in selection of participants. Andrews et al had moderate bias with missing data. (Figure 2), (Figure 1S - Weighted Summary plot). Overall ROB for observational studies was assessed as moderate, as majority studies were assessed as having moderate ROB. In addition, adjusted mortality rates were presented, which were less likely to be affected by confounding factors as these factors were adjusted during analysis. Hence ROB assessed for GRADE was regarded as having no serious issues.

\section{Efficacy outcomes}

\section{Mortality}

For unadjusted mortality rate, pooled analysis revealed no difference with tocilizumab treatment in comparison to control group [OR $=0.90(95 \% \mathrm{Cl}=0.74$ 1.11), $p=0.33 ; I^{2}=81 \%$ ] (Figure 3a). This data was extracted from twelve observational studies (OS) with a total of 819 and 1931 patients in tocilizumab and control group, respectively. Sensitivity analysis with exclusion of study done by Sanz et al and Capra et al resulted in $\mathrm{I}^{2}=14 \%$, with significant decrease in overall mortality odds with tocilizumab [OR $\left.=0.65(95 \% \mathrm{Cl}=0.50-0.84), p=0.001 ;\left.\right|^{2}=14 \%\right]$. Subgroup analysis revealed that tocilizumab significantly decrease mortality in mild to moderate patients $\left[\mathrm{OR}=0.40(95 \% \mathrm{Cl}=0.23-0.69), \mathrm{p}=0.001 ; \mathrm{I}^{2}=76\right]$ but no difference in severe patients $[\mathrm{OR}=1.05(95 \% \mathrm{Cl}=$ $\left.0.84-1.31), p=0.68 ; I^{2}=81 \%\right]$.

For adjusted mortality, pooled analysis showed decrease in adjusted hazard ratio $(\mathrm{HR})$ with tocilizumab versus control group $[\mathrm{HR}=0.54(95 \% \mathrm{Cl}=0.44-0.68)$, $p<0.00001 ; l^{2}=74 \% ; 6$ OS] (Figure $\left.3 b\right)$. Sensitivity analysis was not performed as all studies showed decrease mortality with tocilizumab and hence heterogeneity was ignored.

\section{Progression of Disease - ICU admission or Need for ventilation (Intubation)}

Pooled analysis revealed statistically significant decrease in number of individuals with progression of disease with tocilizumab treatment in comparison to control group [OR $=0.34(95 \% \mathrm{Cl}=0.21-0.55), \mathrm{p}<0.0001 ; \mathrm{l}^{2}=76 \%$ ] (Figure 4). This data was extracted from five OS with a total of 212 patients in tocilizumab group and 266 in control group. Sensitivity analysis was not performed as heterogeneity is because of difference in characteristics of patients included in studies of review. Therefore, GRADE quality of evidence is downgraded for increased heterogeneity.

\section{Hospital discharge}

Pooled analysis revealed that there was no difference in odds of hospital discharge in tocilizumab group as compared to standard of care [OR $=1.35$ ( $95 \% \mathrm{Cl}$ $\left.=0.84-2.18), p=0.22 ; I^{2}=22 \%\right]$ (Figure 2S). Data extracted from 4 OS with 157 and 175 patients in two groups respectively.

\section{Clinical Improvement}

No statistically significant difference in the rate of clinical improvement was observed between two treatment groups [OR $=1.02(95 \% \mathrm{Cl}=0.61-1.69)$, $\left.p=0.95 ; l^{2}=84 \%\right]$ (Figure 3S). Results derived from 4 OS with 164 and 148 patients in tocilizumab and control group, respectively.

\section{Safety outcomes}

\section{Secondary Bacteraemia}

There was a significant increase in odds of secondary bacteraemia in individuals treated with tocilizumab versus control [OR $=2.75(95 \% \mathrm{Cl}=1.86-4.06), \mathrm{p}<$ $0.00001 ;\left.\right|^{2}=84 \%$ ] (Figure $5 a$ ). This data was extracted from 3 OS with a total of 254 and 558 patients in tocilizumab and control groups, respectively.

\section{Secondary pneumonia or superinfections}

There was a significant increase in odds of secondary pneumonia or superinfections in individuals treated with tocilizumab versus control [OR $=2.93$ ( $95 \% \mathrm{Cl}$ $=1.92-4.46), p<0.00001 ;\left.\right|^{2}=77 \%$ ] (Figure $5 b$ ). This data was extracted from 4 OS with a total of 282 and 581 patients in tocilizumab and control groups, respectively.

\section{Publication bias}

Publication bias was low, the funnel plot for twelve studies appears to be asymmetrical around the intervention effect estimate for mortality rate (Figure 4S). Regression test for funnel plot asymmetry showed the value of $t=-1.3752$ and $p$-value of 0.1991 , indicating low publication bias. Egger's regression test for progression of disease $(t=0.1022, p$-value $=0.9251)$, hospital discharge $(t=-0.8767, p$-value $=0.4731)$ and clinical improvement $(t=-2.4392, p$-value $=0.1349)$ showed low publication bias. Hence, overall publication bias was concluded as low for systematic review. 


\section{GRADE analysis of the primary and secondary outcomes (Table 2)}

The GRADE recommendation for the primary outcome adjusted HR for mortality was 'HIGH' evidence quality as there were no serious issues in the ROB analysis, inconsistency, indirectness with lack of imprecision. ROB is regarded as low as all the confounders were adjusted during analysis. As all the studies showed mortality benefit with tocilizumab with adjusted HR, heterogeneity was ignored. However, for non-adjusted mortality rate, recommendation is low, as there is high heterogeneity along with high ROB. In addition, there was imprecision of results along with plausible confounding suggesting spurious effect. The GRADE recommendation for progression of disease was graded as 'Moderate' evidence quality because of moderate ROB and high heterogeneity. The recommendation for hospital discharge and clinical improvement were graded as "Low" and "Very Low" respectively. The GRADE recommendation for secondary bacteraemia and pneumonia or superinfections were "High" and "Moderate" evidence quality respectively, as there was presence of serious issues with ROB and high heterogeneity. The GRADE recommendation is shown in table 2.

\section{Discussion}

Despite the existing dilemma on whether there is benefit with the use of tocilizumab in COVID patients and increased risk of secondary infections, tocilizumab is being recommended worldwide and is being used by many clinicians in critically ill patients or patients with cytokine storm. The existing review was done for the risk-benefit assessment of tocilizumab in high-risk COVID-19 patients.

Amongst 13 studies shortlisted for analysis, five studies recruited moderate severity patients from ward or who were not on mechanical ventilation. While in other five studies, design criteria included only severely diseased patients either in ICU or on some form of non-invasive or invasive ventilation. Unlike randomized controlled trials, observational studies have inherent biases in patient allocations that cannot be fully adjusted for during statistical analyses. Although propensity modelling to mitigate known imbalances was done, it is possible that unmeasured confounding factors may still be important. Out of thirteen, 6 studies had a treatment selection bias as tocilizumab was started or given to worsening or only severely ill patients.

Colaneri et al in their study of 21 patients not requiring mechanical ventilation at admission found no significant benefit of Tocilizumab in preventing ICU admission or mortality. It may be because their outcome of mortality was measured at 7 day time line in contrast to other studies who assessed 28 day mortality.

Similarly Campochiaro et al studied moderately diseased COVID patients outside ICU and reported mortality rate of $15 \%$ in tocilizumab group versus $33 \%$ in non- tocilizumab group. However there was no statistically significant mortality benefit of tocilizumab over standard care. This again may support the existing literature that tocilizumab is advocated for severely ill patients and in moderate disease, benefit is not very evident.

In current systematic review, unadjusted ORs for mortality demonstrated that tocilizumab was associated with no mortality benefit as compared to control. However adjusted HR showed there was significant decrease in probability of death with tocilizumab. The results of adjusted HR were more valid as there were higher number of co-morbidities or more severe patients in tocilizumab group in six studies. Hence, the results of unadjusted OR should be interpreted in the light of adjustment of these covariates. This could be appreciated most in the study by Sanz et al in which Tocilizumab group had patients with greater disease severity in terms of more patients with pre-existing lung disease and diabetes. Thus the unadjusted OR favoured the control group while adjusted hazards ratio addressing the severity bias turned the results in favour of tocilizumab decreasing the chances of mortality. Andrew et al did a proportional hazard model in which patients were stratified into propensity score quintiles for adjustment of factors contributing significantly to the outcome other than treatment. Most of the studies have added tocilizumab to the intervention group over and above the standard therapy. However in study by Andrews et al, standard therapy as adjunct was given to statistically significant less number of patients in tocilizumab group. Had tocilizumab been administered along with standard therapy the results could have been more in favour of experimental group. Andrews et al had the largest weight amongst the studies due to maximum number of events with a large sample size and thus had a great influence in the final result. Capra et al performed Cox proportional-hazard model, adjusting for baseline variables age, sex, comorbidities like diabetes, hypertension, heart disease and serum polymerase chain reaction (PCR) at baseline. Ramaswamy's study was similar to Capra et al with inclusion of adjustment for Elixhauser-van Walraven comorbidity score, average modified early warning score (MEWS), highest level of care (ICU, Progressive, etc.), if mechanical ventilation was required, number of opioid doses, number of anti-diabetic drug doses, number of anticoagulant doses and number of antibiotic doses. Rossi et al did propensity score matching at baseline with additional Cox multivariate analysis with adjustment of confounders. Somers et al performed multivariable Cox regression with propensity score inverse probability weighting (IPTW).

Increased heterogeneity is because of variation in study population in the included studies. Hence, there is difference in effect estimate and confidence interval of included studies. Sensitivity analysis with exclusion of Sanz et al and Capra et al showed mortality benefit with tocilizumab group as compared to standard therapy along with low heterogeneity of $14 \%$. Sanz et al was excluded in the sensitivity analysis as significantly more severe patients were enrolled in tocilizumab group (pulmonary disease, along with increased CRP and IL-6). In Sanz et al study, sensitivity analysis of subjects with baseline CRP levels above $150 \mathrm{mg} / \mathrm{L}$ and treated with tocilizumab had experienced lower rates of death (aHR 0.34, 95\% $\mathrm{Cl} 0.17-0.71, \mathrm{p}=0.005$ ) and ICU admission/death (aHR $0.39,95 \%$ $\mathrm{Cl} 0.19-0.80, \mathrm{p}=0.011$ ) as compared to standard care. In sub-group with baseline CRP levels $\leq 150 \mathrm{mg} / \mathrm{dL}$, this effect was not observed.

Sensitivity analysis was not performed for progression of disease and clinical improvement. In addition, no adjustment was done for the confounding factors, more prevalent in tocilizumab group. Hence, these outcomes were downgraded for evidence both for ROB and inconsistency in GRADE quality assessment. In addition as there is no difference in pooled effect estimate, both outcomes were downgraded for lack of imprecision also.

We found that patients receiving tocilizumab were associated with $66 \%$ decrease in odds of disease progression compared to control group, even though the drug was administered to more severe patients. There was no significant difference in odds of discharge from hospital as well as clinical improvement in two treatment group. This may be due to lesser number of studies that had reported these two outcomes. Usually it was expected to have increase clinical 
improvement as well as hospital discharge. The other reason attributed could be the fact that patients with greater disease severity were administered Tocilizumab at times even after failure of standard therapy.[23]

Serious adverse event of concern with tocilizumab is secondary bacteraemia and secondary pneumonia. Significant increase in odds of secondary bacteraemia and secondary pneumonia in patients treated with tocilizumab versus control was found in our systematic review. This is due to decrease in IL-6 inside the body, which is essential in combating the life threatening infections. However despite high rates of superinfection reported with tocilizumab no statistically significant deaths were reported.[26] Capra et al and Colaneri et al have reported absence of any adverse events in their cohorts. Capra et al included all moderately diseased patients and administered a dose of $400 \mathrm{mg}$ of Tocilizumab irrespective of weight which could have resulted in the absence of any adverse effects noted. It could be implied that in mild to moderate patients with minimal oxygen requirement lesser dose may be advocated to minimize adverse events. Higher tocilizumab dose (maximum $800 \mathrm{mg}$ ) could have played a role in the increased rate of infections observed in other studies. Colaneri et al evaluated end point at 7 days which could have been the reason for no adverse events reported.

The proposed mechanism of action of tocilizumab is inhibition of IL-6. This is one of the major cytokine involved in cytokine storm as well as patients with happy hypoxia. Hence, inhibition of this cytokine has led to colossal benefit with regard to mortality. To assess whether repeated tocilizumab administrations were associated with different clinical outcomes, further studies may be required. Though we compared re-treated patients with those treated with a single tocilizumab infusion; however, no statistically significant difference emerged.

\section{Limitations And Strengths}

A major shortcoming is our systematic review is of observational studies only, due to no completed clinical trials to date. Inherent selection bias in observational studies due to higher likelihood of administering tocilizumab to patients with severs disease and poor prognostic factors must be duly considered while interpreting our conclusions.

The strength is that we did GARDE analysis on the basis of which the results of unadjusted mortality rate were not given due consideration as further research is very likely to have impact on our confidence in the estimate of effect and likely to change the unadjusted mortality rate. Therefore, adjusted HR for mortality was interpreted (High quality evidence - GRADE) and conclusion of decrease mortality with tocilizumab was drawn.

Quality of Evidence: (GRADE)

The overall quality of systematic review is moderate to high as the critical outcomes like mortality (adjusted HR) and progression of disease have high to moderate quality of evidence respectively. Other critical outcomes like secondary pneumonia and superinfections also have a high and moderate quality of evidence, respectively. This evidence suggests that further research is likely to have an important impact on our confidence in the estimate and may change the estimate in case of progression of disease and superinfections but unlikely to have an effect on estimate in case of mortality (adjusted HR).

\section{Conclusion}

Existing evidence from present systematic review of observational studies of tocilizumab in COVID-19 patients indicates a significant reduction in mortality rate (adjusted HR $-46 \%$ reduction of probability) with tocilizumab, alongside high quality of evidence. Progression of disease was observed in a significantly less number of individuals using tocilizumab with moderate quality of evidence. No difference in hospital discharge and clinical improvement was observed in patients using tocilizumab, with low and very low quality of evidence. Tocilizumab usage was associated with 1.75 and 1.93 increased odds of secondary bacteraemia and superinfections, with high and moderate quality evidence, respectively.

Further randomized clinical studies will be useful in order to better clarify the current results that seem to provide initial support to the administration of tocilizumab in patients with COVID-19 pneumonia in order to prevent the complications due to cytokine storm and reduce mortality.

\section{Abbreviation List}

COVID-Corona Virus Disease

IL-6 - Interleukin (IL)-6

TNF-a- Tumour Necrosis Factor

GM-CSF- Granulocyte-macrophage colony stimulating factor

TH-17 - T-helper cells

TCZ - Tocilizumab

HCQ- Hydroxychloroquine

PRISMA - Preferred Reporting Items for Systematic Reviews and Meta-Analyses

PROSPERO - International Prospective Register of Systematic Reviews

ROBINS-I - The Risk Of Bias In Non-randomized studies of Interventions 
Cl: Confidence interval

OR - Odd ratios

HR - Hazard ratios

GRADE pro GDT - Grades of Recommendations, Assessment, Development and Evaluations (GRADE) guideline development tool

OIS - Optimal information size

PCR - Polymerase chain reaction

MEWS - Modified early warning score

CRP - C-REACTIVE PROTEIN

CRS - Cytokine release syndrome

IPTW - Inverse probability weighting (propensity score)

\section{Declarations}

Ethical approval and consent to participate: Not applicable

Consent for publication: Not applicable

Availability of supporting Data: The datasets used and/or analyzed during the current study are available from the corresponding author on request

Competing Interests: Dr. SINGH has nothing to disclose. Dr. KHERA has nothing to disclose. Dr. Mittal N has nothing to disclose, Dr. CHUGH A has nothing to disclose. Dr Mittal R nothing to disclose. Dr. CHUGH V has nothing to disclose.

Funding: None declared

\section{Authors Contribution:}

Study design and planning of systematic review - All of the authors

Literature search - NM, RM, SS

Figures - SS, VKC, AC

Tables - NM, SS, AC, VKC

Data collection and analysis - SS, NM, RM

ROB - DK, AC, SS, Query resolved by all authors

GRADE Analysis - SS, AC, DK, Query resolved by all authors

Data interpretation -, SS, DK, AC, NM

Writing - SS, DK, AC, NM, VKC

Corrections and Final approval of Manuscript - All of the authors

The corresponding author attests that all listed authors meet authorship criteria as per ICJME and that the manuscript is an honest, accurate, and transparent account of the study being reported

\section{Acknowledgements:}

We acknowledge GRADE Pro team [McMaster University and Evidence Prime Inc. available from: https://gradepro.org/] for letting us use the software for the synthesis and overall assessment and grading of systematic review.

Authors and Affiliations:

\section{Dr. Surjit Singh}

Additional Professor, Department of Pharmacology, All India Institute of Medical Sciences, Jodhpur, India.

\section{Dr. Daisy Khera}


Additional Professor, Department of Pediatrics, All India Institute of Medical Sciences, Jodhpur, India.

\section{Dr. Ankita Chugh and Dr. Vinay Kumar Chugh}

Additional Professor, Department of Dentistry, All India Institute of Medical Sciences, Jodhpur, India.

\section{Dr. Niti Mittal and Dr. Rakesh Mittal.}

Department of Pharmacology, Postgraduate Institute of Medical Sciences, Rohtak, India.

\section{References}

1. Xu Z, Shi L, Wang Y, Zhang J, Huang L, Zhang C, et al. Pathological findings of COVID-19 associated with acute respiratory distress syndrome. Lancet Respir Med. 2020 Apr;8(4):420-2.

2. Chen N, Zhou M, Dong X, Qu J, Gong F, Han Y, et al. Epidemiological and clinical characteristics of 99 cases of 2019 novel coronavirus pneumonia in Wuhan, China: a descriptive study. Lancet. 2020 Feb 15;395(10223):507-13.

3. Huang C, Wang Y, Li X, Ren L, Zhao J, Hu Y, et al. Clinical features of patients infected with 2019 novel coronavirus in Wuhan, China. Lancet. 2020 Feb;15(10223):497-506. 395(.

4. Xu X, Han M, Li T, Sun W, Wang D, Fu B, et al. Effective treatment of severe COVID-19 patients with tocilizumab. Proc Natl Acad Sci U S A. 2020 May 19;117(20):10970-5.

5. Chiaretti A, Pulitano S, Barone G, Ferrara P, Romano V, Capozzi D, et al. IL-1 beta and IL-6 upregulation in children with H1N1 influenza virus infection. Mediators Inflamm. 2013;2013:495848.

6. Cytokine Storm Drugs. Move from CAR T to COVID-19. Cancer Discov. 2020 Jul;10(7):OF8.

7. 10.1101/2020.05.21.20109207v1 Ip A, Berry D, Hansen E, Goy A, Pecora A, Sinclaire B, et al. Hydroxychloroquine and Tocilizumab Therapy in COVID-19 Patients - An Observational Study. 2020. Available from: https://www.medrxiv.org/content/10.1101/2020.05.21.20109207v1.

8. Capra R, De Rossi N, Mattioli F, Romanelli G, Scarpazza C, Sormani MP, et al. Impact of low dose tocilizumab on mortality rate in patients with COVID-19 related pneumonia. Eur J Intern Med. 2020 Jun;76:31-5.

9. Kewan T, Covut F, Al-Jaghbeer MJ, Rose L, Gopalakrishna KV, Akbik B. Tocilizumab for treatment of patients with severe CoVID-19: A retrospective cohort study. EClinicalMedicine (2020), https://doiorg/101016/jeclinm2020100418. 2020.

10. Ramaswamy M, Mannam P, Comer R, Sinclair E, McQuaid DB, Schmidt ML. Off-Label Real World Experience Using Tocilizumab for Patients Hospitalized with COVID-19 Disease in a Regional Community Health System: A Case-Control Study. medRxiv;. 2020.

11. Martinez-Sanz J, Muriel A, Ron R, Herrera S, Perez-Molina J, Moreno S, et al. Effects of Tocilizumab on Mortality in Hospitalized Patients with COVID-19: A Multicenter Cohort Study. medRxiv; 2020 Available from: https://wwwmedrxivorg/content/101101/2020060820125245v1.

12. Sterne JA, Hernan MA, Reeves BC, Savovic J, Berkman ND, Viswanathan M, et al. ROBINS-I: a tool for assessing risk of bias in non-randomised studies of interventions. BMJ. 2016 Oct;12:355:i4919.

13. McGuinness LA, Higgins JPT. Risk-of-bias VISualization (robvis): An R package and Shiny web app for visualizing risk-of-bias assessments. Res Synth Methods. 2020 Apr 26.

14. Copenhagen. The Nordic Cochrane Centre. The Cochrane Collaboration. Review Manager (RevMan) [Computer program]. Version 5.3.

15. Higgins J, Green S, editors. Cochrane Handbook for Systematic Reviews of Interventions: The Cochrane Collaboration, $2011 ; 2011$ [cited 202028 May]. Available from: .

16. Higgins JP, Thompson SG, Deeks JJ, Altman DG. Measuring inconsistency in meta-analyses. BMJ. 2003 Sep 6;327(7414):557-60.

17. Kjaergard LL, Villumsen J, Gluud C. Reported methodologic quality and discrepancies between large and small randomized trials in meta-analyses. Ann Intern Med. 2001 Dec;4(11):982-9. 135(.

18. Schünemann H, Brożek J, Guyatt G, Oxman A, editors. GRADE handbook for grading quality of evidence and strength of recommendations. Updated October 2013. The GRADE Working Group, 2013. 2013. Available from: guidelinedevelopment.org/handbook.

19. GRADEpro GDT: GRADEpro Guideline Development Tool [Software]. McMaster University, 2015 (developed by Evidence Prime, Inc.). [database on the Internet]. Available from: gradepro.org.

20. Campochiaro C, Della-Torre E, Cavalli G, De Luca G, Ripa M, Boffini N, et al. Efficacy and safety of tocilizumab in severe COVID-19 patients: a single-centre retrospective cohort study. Eur J Intern Med. 2020 Jun;76:43-9.

21. Colaneri M, Bogliolo L, Valsecchi P, Sacchi P, Zuccaro V, Brandolino F, et al. Tocilizumab for Treatment of Severe COVID-19 Patients: Preliminary Results from SMAtteo COvid19 REgistry (SMACORE). Microorganisms. 2020 May 9;8(5).

22. Moreno Garcia E, Rico Caballero V, Albiach L, Aguero D, Ambrosioni J, Bodro M, et al. Tocilizumab is associated with reduction of the risk of ICU admission and mortality in patients with SARS-CoV-2 infection. medRxiv; 2020.

23. Klopfenstein T, Zayet S, Lohse A, Balblanc JC, Badie J, Royer PY, et al. Tocilizumab therapy reduced intensive care unit admissions and/or mortality in COVID-19 patients. Med Mal Infect. 2020 May 6.

24. Quartuccio L, Sonaglia A, McGonagle D, Fabris M, Peghin M, Pecori D, et al. Profiling COVID-19 pneumonia progressing into the cytokine storm syndrome: Results from a single Italian Centre study on tocilizumab versus standard of care. J Clin Virol. 2020 May 15;129:104444. 
25. Rossi B, Nguyen L, Zimmermann P, Boucenna F, Dubret L, Baucher L, et al. Effect of tocilizumab in hospitalized patients with severe pneumonia COVID-19: a cohort study. medRxiv 2020.

26. Somers E, Eschenauer G, Troost J, Golob J, Gandhi T, Wang L, et al. Tocilizumab for treatment of mechanically ventilated patients with COVID-19. medRxiv; 2020 Available from: https://wwwmedrxivorg/content/101101/2020052920117358v1.

27. Wadud N, Ahmed N, Shergil M, Khan M, Krishna M, Gilani A, et al. Improved survival outcome in SARs-CoV-2 (COVID-19) Acute Respiratory Distress Syndrome patients with Tocilizumab administration. medRxiv; 2020 Available from: https://wwwmedrxivorg/content/101101/2020051320100081v1.

\section{Tables}

Table 1. Characteristics of clinical studies evaluating tocilizumab for treatment of COVID-19 


\begin{tabular}{|c|c|c|c|c|c|}
\hline $\begin{array}{l}\text { Study ID } \\
\text { (Study } \\
\text { design) }\end{array}$ & $\begin{array}{l}\text { Institution/ } \\
\text { Country of } \\
\text { study } \\
\text { conduct }\end{array}$ & $\begin{array}{l}\text { Study } \\
\text { Interventions } \\
(\mathrm{N}) / \\
\text { Regimen }\end{array}$ & $\begin{array}{l}\text { Study control }(\mathrm{N}) / \\
\text { Regimen }\end{array}$ & $\begin{array}{l}\text { Study } \\
\text { population } \\
\text { characteristics }\end{array}$ & Study outcomes \\
\hline $\begin{array}{l}\text { Andrew et al } \\
2020 \text { [15] } \\
\text { (Retrospective } \\
\text { multicenter } \\
\text { cohort study) }\end{array}$ & $\begin{array}{l}\text { Hackensack } \\
\text { Meridian } \\
\text { Health } \\
\text { network } \\
\text { (HMH) } \\
\text { New Jersey }\end{array}$ & $\begin{array}{l}\text { Tocilizumab } \\
\text { (134); at } \\
\text { least } 1 \text { dose } \\
\text { after } \\
\text { entering ICU }\end{array}$ & $\begin{array}{l}\text { No tocilizumab } \\
(413)\end{array}$ & $\begin{array}{l}\text { Hospitalised } \\
\text { (ICU) COVID- } \\
\text { 19 patients; } \\
\text { Males: } \\
356 / 547 \\
(65 \%) \\
\text { Age [median } \\
\text { (IQR)]: } 67 \text { (58- } \\
\text { 76)years }\end{array}$ & $\begin{array}{l}\text { Mortality: Tocilizumab: [adjusted Hazard ratio (aHR: } 0.76 \text {; } \\
95 \% \text { Cl: } 0.57-1.00 ; P=0.053) \text { ]; } 30 \text { day mortality rate : } 46 \% \text { in } \\
\text { tocilizumab vs } 56 \% \text { in control groups }\end{array}$ \\
\hline $\begin{array}{l}\text { Campochiaro } \\
\text { et al 2020 [16] } \\
\text { (single center } \\
\text { retrospective } \\
\text { cohort study) }\end{array}$ & $\begin{array}{l}\text { San } \\
\text { Raffaele } \\
\text { Hospital, } \\
\text { Milan, } \\
\text { Italy }\end{array}$ & $\begin{array}{l}\text { Tocilizumab } \\
\text { (32) }\end{array}$ & $\begin{array}{l}\text { Standard treatment } \\
\text { (33) }\end{array}$ & $\begin{array}{l}\text { Hospitalised } \\
\text { (non-ICU) } \\
\text { COVID-19 } \\
\text { patients; } \\
\text { Males: } 56 \\
\text { (86\%), Age } \\
\text { [median } \\
\text { (IQR)]:64 (53- } \\
\text { 75) in } \\
\text { tocilizumab vs } \\
60 \text { (55-75.5) } \\
\text { yrs in control } \\
\text { group }\end{array}$ & $\begin{array}{l}\text { Over } 28 \text {-day follow-up: Mortality: } 5(16 \%) \text { patients in } \\
\text { tocilizumab vs } 11(33 \%) \text { in control groups; } p=0.15 \text {. Need for } \\
\text { mechanical ventilation: } 4(13 \%) \text { vs } 2(6 \%) \text { in tocilizumab and } \\
\text { control groups respectively; } p=0.43 \text {. Rate of discharge from } \\
\text { hospital: } 20(63 \%) \text { vs } 16(49 \%) \text { in tocilizumab and control } \\
\text { groups respectively; } p=0.32 \text {. Median time to discharge: } 13.5(10 \\
-16.7) \text { for tocilizumab versus } 14(12-15.5) \text { days for control; } p \\
=0.99 \text {. Clinical improvement: } 22(69 \%) \text { patients of the } \\
\text { tocilizumab group and in } 20 \text { patients }(61 \%) \text { of the control group, } \\
p=0.61 \text {. Serious adverse events: } 8(25 \%) \text { patients in } \\
\text { tocilizumab group vs } 9(27 \%) \text { patients in control group }\end{array}$ \\
\hline $\begin{array}{l}\text { Capra et al } \\
2020 \text { [17] } \\
\text { (retrospective } \\
\text { observational } \\
\text { study) }\end{array}$ & $\begin{array}{l}\text { Montichiari } \\
\text { Hospital, } \\
\text { Italy }\end{array}$ & $\begin{array}{l}\text { Tocilizumab } \\
\text { (62) }\end{array}$ & $\begin{array}{l}\text { Standard (HCQ + } \\
\text { Lopinavir/ritonavir) } \\
(23)\end{array}$ & $\begin{array}{l}\text { Hospitalised } \\
\text { patients with } \\
\text { COVID-19 } \\
\text { related } \\
\text { pneumonia } \\
\text { and } \\
\text { respiratory } \\
\text { failure, not } \\
\text { needing } \\
\text { mechanical } \\
\text { ventilation; } \\
\text { Males: } 64 \\
\text { (75\%), Age } \\
\text { [median } \\
\text { (IQR)]:65 } \\
\text { [54.5-73], yrs }\end{array}$ & $\begin{array}{l}\text { Mortality: adjusted hazard ratio: } 0.035(0.004-0.347) \mathrm{p}=0.004 \text {. } \\
\text { Mortality rate, } n \text { (\% on patients with known clinical outcome): } 2 \\
(8 \%) \text { in tocilizumab vs } 11(57.9 \%) \text { in control groups. } \\
\text { Improved/discharged, } n(\% \text { on patients with known clinical } \\
\text { outcome): } 23(92 \%) \text { vs } 8(42.1 \%) \text { in tocilizumab and control } \\
\text { groups respectively. Days to discharge, median(range): } 12.5 \text { (4- } \\
\text { 18) vs } 8 \text { (7-15) days in tocilizumab and control groups } \\
\text { respectively. }\end{array}$ \\
\hline $\begin{array}{l}\text { Colaneri et al } \\
2020 \text { [18] } \\
\text { (registry } \\
\text { analysis) }\end{array}$ & $\begin{array}{l}\text { IRCCS } \\
\text { Policlinico } \\
\text { San Matteo } \\
\text { Hospital, } \\
\text { Pavia, Italy }\end{array}$ & $\begin{array}{l}\text { Tocilizumab } \\
\text { (21) }\end{array}$ & $\begin{array}{l}\text { Standard of care } \\
\text { (SOC) (91) }\end{array}$ & $\begin{array}{l}\text { Critically ill } \\
\text { patients with } \\
\text { severe COVID- } \\
19 \\
\text { pneumonia; } \\
\text { Males: } 82 \\
\text { (73\%); Age: } \\
63.5 \text { (16.9) yrs }\end{array}$ & $\begin{array}{l}\text { ICU admission: Odds Ratio: } 0.11(0.00-3.38) ; p=0.22 .7 \text {-day } \\
\text { mortality rate: odds ratio: } 0.78(0.06-9.34) ; p=0.84 \text {. Safety: no } \\
\text { adverse events in tocilizumab group }\end{array}$ \\
\hline $\begin{array}{l}\text { Garcia et al } \\
2020 \text { [19] } \\
\text { (retrospective } \\
\text { study) }\end{array}$ & $\begin{array}{l}\text { Hospital } \\
\text { clinic of } \\
\text { Barcelona, } \\
\text { Spain }\end{array}$ & $\begin{array}{l}\text { Tocilizumab } \\
\text { (77) }\end{array}$ & $\begin{array}{l}\text { SOC }(\mathrm{HCQ}+ \\
\text { Lopinavir/ritonavir, } \\
\text { antibiotics) (94) }\end{array}$ & $\begin{array}{l}\text { Non-critically } \\
\text { ill COVID-19 } \\
\text { patients. } \\
\text { Males: } 112 \\
\text { (65.5\%); Age: } \\
61.5(12.4) \text { yrs } \\
\text { in tocilizumab } \\
\text { vs } 61.4(16) \\
\text { yrs in control } \\
\text { group }\end{array}$ & $\begin{array}{l}\text { Patients in Tocilizumab group has more frequently fever, } \\
\text { pneumonia (interstitial infiltrates) and more need of oxygen } \\
\text { therapy. In addition, increased C-reactive protein (CRP) levels } \\
\text { ( } p=0.04 \text { ) in tocilizumab group. } \\
\text { ICU admission: } 10.3 \% \text { in tocilizumab vs. } 27.6 \% \text { in control group, } \\
p=0.005 \text {. Need of invasive ventilation: } 0 \text { vs } 13.8 \% \text { in } \\
\text { tocilizumab and control groups respectively; } p=0.001 \text {. Mortality: } \\
10.3 \% \text { vs } 18 \% \text { in tocilizumab and control groups respectively. }\end{array}$ \\
\hline $\begin{array}{l}\text { Kewan et al } \\
\text { [14] } \\
\text { (retrospective } \\
\text { cohort study) }\end{array}$ & $\begin{array}{l}\text { Cleveland } \\
\text { Clinic } \\
\text { Fairview } \\
\text { Hospital, US }\end{array}$ & $\begin{array}{l}\text { Tocilizumab } \\
\text { (28) }\end{array}$ & $\begin{array}{l}\text { Standard of care } \\
(23)\end{array}$ & $\begin{array}{l}\text { Hypoxic } \\
\text { COVID-19 } \\
\text { patients. } \\
\text { Males: } 20 \\
\text { (71\%); Age } \\
\text { median: } 62 \\
\text { yrs in } \\
\text { tocilizumab vs } \\
70 \text { yrs in } \\
\text { control group }\end{array}$ & $\begin{array}{l}\text { Tocilizumab cohort was sicker because more patients required } \\
\text { admission to intensive care unit ( } 86 \% \text { vs. } 70 \%, p=0.19) \text {, } \\
\text { invasive mechanical ventilation }(75 \% \text { vs. } 48 \%, p=0.046) \text {, } \\
\text { vasopressor support ( } 57 \% \text { vs. } 39 \%, p=0.2) \text {, and renal } \\
\text { replacement therapy ( } 25 \% \text { vs. } 9 \%, p=0.16) \text { during } \\
\text { hospitalization as compared to patients in no tocilizumab } \\
\text { cohort. } \\
\text { Single intravenous infusion of low-dose tocilizumab } \\
\text { (8mg/kgupto400mg). } \\
\text { Hospital discharge - } 11(39 \%) \text { - Tocilizumab and } 13(57 \%) \text { - } \\
\text { Control group. } \\
\text { Mortality - } 3(10.7 \%) \text { and } 2(8.7 \%) \text { in tocilizumab and control } \\
\text { groups respectively. }\end{array}$ \\
\hline
\end{tabular}




\begin{tabular}{|c|c|c|c|c|c|}
\hline $\begin{array}{l}\text { Klopfenstein } \\
\text { et al } 2020[21] \\
\text { (retrospective } \\
\text { case-control } \\
\text { study) }\end{array}$ & $\begin{array}{l}\text { Nord } \\
\text { Franche- } \\
\text { Comté } \\
\text { Hospital, } \\
\text { France }\end{array}$ & $\begin{array}{l}\text { Tocilizumab } \\
\text { (20) }\end{array}$ & $\begin{array}{l}\text { Standard of care } \\
\text { (HCQ + } \\
\text { Lopinavir/ritonavir, } \\
\text { antibiotics) (25) }\end{array}$ & $\begin{array}{l}\text { Critically ill } \\
\text { COVID-19 } \\
\text { patients. Age: } \\
76.8 \text { (52-93) } \\
\text { yrs in } \\
\text { tocilizumab } \\
\text { and } 70.7 \text { (33- } \\
96) \text { yrs in } \\
\text { control group. }\end{array}$ & $\begin{array}{l}\text { Tocilizumab group have high Charlson comorbidity index, } \\
\text { increased lymphocytes, CRP and } 60 \% \text { patients with }>50 \% \text { lung } \\
\text { involvement as compared to control group ( } 25 \%) \text {. } \\
\text { Composite end point of death and/or ICU admissions: } 25 \% \text { vs } \\
72 \% \text { in tocilizumab and control groups respectively; } p=0.002 \text {. }\end{array}$ \\
\hline $\begin{array}{l}\text { Quartuccio et } \\
\text { al 2020 [22] } \\
\text { (retrospective } \\
\text { study) }\end{array}$ & $\begin{array}{l}\text { University } \\
\text { of Udine, } \\
\text { Udine, Italy }\end{array}$ & $\begin{array}{l}\text { Tocilizumab } \\
(42)\end{array}$ & $\begin{array}{l}\text { Standard of care } \\
\text { (69) }\end{array}$ & $\begin{array}{l}\text { Hospitalised } \\
\text { COVID-19 } \\
\text { patients. } \\
\text { Males: } 77 \\
(69.4 \%) ; \text { Age: } \\
58.5 \pm 13.6 \\
\text { years }\end{array}$ & $\begin{array}{l}\text { Tocilizumab group has significantly higher level of } \\
\text { inflammation ( } \uparrow \text { CRP, IL- } 6 \text { levels) and higher systemic disease } \\
\text { and organ damage }(\uparrow \text { Lactate dehydrogenase (LDH) and } \\
\text { Creatinine Kinase (CK) - probable cardiac damage) at baseline. } \\
\text { Mortality: } 4(9.5 \%) \text { in tocilizumab group vs } 0 \text { in SOC group. } \\
\text { Clinical recovery: } 30 \text { ( } 71.4 \%) \text { in tocilizumab and } 100 \% \text { in SOC } \\
\text { group. Adverse events: Bacterial superinfection: } 18(42.8 \%) \\
\text { patients in tocilizumab vs none in SOC group. } \\
\text { *Patients with adverse prognostic markers were given } \\
\text { tocilizumab }\end{array}$ \\
\hline $\begin{array}{l}\text { Ramaswamy } \\
\text { et al } 2020[23] \\
\text { (case control } \\
\text { study) }\end{array}$ & $\begin{array}{l}\text { LeBauer } \\
\text { Healthcare } \\
\text { at Cone } \\
\text { Health, } \\
\text { Greensboro } \\
\text { NC }\end{array}$ & $\begin{array}{l}\text { Tocilizumab } \\
\text { (21) }\end{array}$ & $\begin{array}{l}\text { No tocilizumab } \\
(65)\end{array}$ & $\begin{array}{l}\text { Hospitalised } \\
\text { COVID-19 } \\
\text { patients. } \\
\text { Males: } 49 \\
\text { (57\%); Age: } \\
63.7 \pm 15.7 \text { yrs }\end{array}$ & $\begin{array}{l}\text { Tocilizumab group has high CRP and IL- } 6 \text { levels, high average } \\
\text { modified early warning score (MEWS), more patients requiring } \\
\text { mechanical ventilation, continuous renal replacement therapy. } \\
\text { Inpatient mortality: } 3 \text { (14.3\%) in tocilizumab vs } 8(12.3 \%) \text { in } \\
\text { control group; } p=0.81 \text {; adjusted hazard ratio: } 0.25,0.07-0.90 \text {. }\end{array}$ \\
\hline $\begin{array}{l}\text { Rossi et al } \\
2020[24] \\
\text { (retrospective } \\
\text { case-control } \\
\text { study) }\end{array}$ & $\begin{array}{l}\text { Robert } \\
\text { Ballanger } \\
\text { regional } \\
\text { hospital, } \\
\text { France }\end{array}$ & $\begin{array}{l}\text { Tocilizumab } \\
(106)\end{array}$ & Controls (140) & $\begin{array}{l}\text { Hospitalised } \\
\text { patients with } \\
\text { severe COVID- } \\
19 \\
\text { pneumonia. } \\
\text { Males: } 151 \\
(61.4 \%), \text { Age: } \\
67.6 \pm 15.3 y r s\end{array}$ & $\begin{array}{l}\text { Composite of all-cause mortality and invasive mechanical } \\
\text { ventilation: Propensity score matched cohort }(n=168) \text { : HR= } 0.49 \text {, } \\
0.3-0.81 ; P=0.005 ; \\
\text { Cox multivariable survival analysis, overall cohort }(n=246) \text { : } \\
\text { adjusted HR: } 0.29,0.17-0.53 ; P<0.00001\end{array}$ \\
\hline $\begin{array}{l}\text { Sanz et al } \\
2020 \text { [25] } \\
\text { (cohort study) }\end{array}$ & Spain & $\begin{array}{l}\text { Tocilizumab } \\
(260)\end{array}$ & Controls (969) & $\begin{array}{l}\text { Hospitalised } \\
\text { COVID-19 } \\
\text { patients. } \\
\text { Males: } 765 \\
\text { (62.2\%); Age: } \\
65(55-76) \text { vs } \\
68(57-80) \text { yrs } \\
\text { in tocilizumab } \\
\text { and control } \\
\text { groups } \\
\text { respectively }\end{array}$ & $\begin{array}{l}\text { Tocilizumab group has high statistically significant increased } \\
\text { CRP and IL- } 6 \text { levels, LDH and absolute neutrophil counts as } \\
\text { compared to SOC } \\
\text { Mortality. Adjusted HR: } 0.34,0.16-0.72, p=0.005) \text {. Composite of } \\
\text { mortality or ICU admission. (aHR: } 0.38,0.19-0.81, p=0.011 \text { ). } \\
\text { *in patients with higher CRP levels }\end{array}$ \\
\hline $\begin{array}{l}\text { Somers et al } \\
2020[26] \\
\text { (cohort study) }\end{array}$ & $\begin{array}{l}\text { University } \\
\text { of } \\
\text { Michigan, } \\
\text { USA }\end{array}$ & $\begin{array}{l}\text { Tocilizumab } \\
\text { (78) }\end{array}$ & $\begin{array}{l}\text { No tocilizumab } \\
\text { (76) }\end{array}$ & $\begin{array}{l}\text { Mechanically } \\
\text { ventilated } \\
\text { patients with } \\
\text { COVID-19. } \\
\text { Males: } 102 \\
(66 \%) \text {; Age: } \\
58 \pm 14.9 \text { yrs }\end{array}$ & $\begin{array}{l}\text { Mortality. Demographic adjusted HR for tocilizumab vs control: } \\
0.54,0.29-1.00 ; p=0.05 \text {. Adverse events. Bacterial } \\
\text { superinfections: } 54 \% \text { vs } 26 \% \text { in tocilizumab and control groups } \\
\text { respectively; } p<0.001\end{array}$ \\
\hline $\begin{array}{l}\text { Wadud et al } \\
2020[27] \\
\text { (retrospective } \\
\text { case-control } \\
\text { study) }\end{array}$ & $\begin{array}{l}\text { Orange } \\
\text { Regional } \\
\text { Medical } \\
\text { Center }\end{array}$ & $\begin{array}{l}\text { Tocilizumab } \\
\text { (44) }\end{array}$ & Controls (50) & $\begin{array}{l}\text { Mechanically } \\
\text { ventilated } \\
\text { patients with } \\
\text { COVID-19. }\end{array}$ & $\begin{array}{l}\text { Statistically significant higher Average HS score ( } 114 \text { in } \\
\text { tocilizumab vs } 92 \text { in control), as well as elevated IL-6, } \\
\text { triglycerides, AST, ferritin in tocilizumab group. } \\
\text { Cytokine release syndrome (CRS) } \\
\text { Survival rate: } 61.36 \% \text { in tocilizumab vs } 48 \% \text { in control group, } \\
\text { p<0.00001 }\end{array}$ \\
\hline
\end{tabular}

Table 2: GRADE recommendation for outcomes evaluated for the use of Tocilizumab in patients with COVID-19 infection caused by SARS-CoV-2 


\begin{tabular}{|c|c|c|c|c|c|c|c|c|c|c|}
\hline \multicolumn{7}{|c|}{ Certainty assessment } & \multicolumn{2}{|l|}{ № of patients } & \multicolumn{2}{|l|}{ Effect } \\
\hline $\begin{array}{l}\text { № of } \\
\text { studies }\end{array}$ & Study design & $\begin{array}{l}\text { Risk of } \\
\text { bias }\end{array}$ & Inconsistency & Indirectness & Imprecision & $\begin{array}{l}\text { Other } \\
\text { considerations }\end{array}$ & Tocilizumab & control & $\begin{array}{l}\text { Relative } \\
\text { (95\% } \\
\text { Cl) }\end{array}$ & $\begin{array}{l}\text { Absolute } \\
\text { (95\% Cl) }\end{array}$ \\
\hline \multicolumn{11}{|c|}{ Mortality } \\
\hline 12 & $\begin{array}{l}\text { observational } \\
\text { studies }\end{array}$ & $\begin{array}{l}\text { serious } \\
\text { a }\end{array}$ & serious $^{b}$ & not serious & serious $^{c}$ & $\begin{array}{l}\text { all plausible } \\
\text { residual } \\
\text { confounding } \\
\text { would suggest } \\
\text { spurious } \\
\text { effect, while } \\
\text { no effect was } \\
\text { observed }\end{array}$ & $\begin{array}{l}189 / 819 \\
(23.1 \%)\end{array}$ & $\begin{array}{l}484 / 1931 \\
(25.1 \%)\end{array}$ & $\begin{array}{l}\text { OR } 0.90 \\
(0.74 \text { to } \\
1.11)\end{array}$ & $\begin{array}{l}19 \text { fewer } \\
\text { per } \\
1,000 \\
\text { (from } 52 \\
\text { fewer to } \\
20 \\
\text { more) }\end{array}$ \\
\hline \multicolumn{11}{|c|}{ Mortality (HR) } \\
\hline 6 & $\begin{array}{l}\text { observational } \\
\text { studies }\end{array}$ & $\begin{array}{l}\text { not } \\
\text { serious } \\
\text { d }\end{array}$ & not serious $^{\mathrm{e}}$ & not serious & not serious & none & $-/ 0$ & $-/ 0$ & $\begin{array}{l}\text { HR } 0.54 \\
(0.44 \text { to } \\
0.68)\end{array}$ & $\begin{array}{l}1 \text { fewer } \\
\text { per } \\
1,000 \\
\text { (from } 1 \\
\text { fewer to } \\
0 \text { fewer) }\end{array}$ \\
\hline \multicolumn{11}{|c|}{ Progression of disease-ICU admission or need of ventilation } \\
\hline 5 & $\begin{array}{l}\text { observational } \\
\text { studies }\end{array}$ & $\begin{array}{l}\text { serious } \\
\text { a }\end{array}$ & serious $^{f}$ & not serious & not serious & $\begin{array}{l}\text { all plausible } \\
\text { residual } \\
\text { confounding } \\
\text { would reduce } \\
\text { the } \\
\text { demonstrated } \\
\text { effect }\end{array}$ & $\begin{array}{l}28 / 212 \\
(13.2 \%)\end{array}$ & $\begin{array}{l}77 / 266 \\
(28.9 \%)\end{array}$ & $\begin{array}{l}\text { OR } 0.34 \\
(0.21 \text { to } \\
0.55)\end{array}$ & $\begin{array}{l}168 \\
\text { fewer } \\
\text { per } \\
1,000 \\
\text { (from } \\
211 \\
\text { fewer to } \\
106 \\
\text { fewer) }\end{array}$ \\
\hline \multicolumn{11}{|c|}{ Hospital discharge } \\
\hline 4 & $\begin{array}{l}\text { observational } \\
\text { studies }\end{array}$ & $\begin{array}{l}\text { serious } \\
\text { a }\end{array}$ & not serious & not serious & serious $^{g}$ & none & $\begin{array}{l}107 / 157 \\
(68.2 \%)\end{array}$ & $\begin{array}{l}111 / 175 \\
(63.4 \%)\end{array}$ & $\begin{array}{l}\text { OR } 1.35 \\
(0.84 \text { to } \\
2.18)\end{array}$ & $\begin{array}{l}66 \text { more } \\
\text { per } \\
1,000 \\
\text { (from } 41 \\
\text { fewer to } \\
157 \\
\text { more) }\end{array}$ \\
\hline \multicolumn{11}{|c|}{ Clinical improvement } \\
\hline 4 & $\begin{array}{l}\text { observational } \\
\text { studies }\end{array}$ & $\begin{array}{l}\text { serious } \\
\text { a }\end{array}$ & serious $^{f}$ & not serious & serious $^{g}$ & none & $\begin{array}{l}120 / 164 \\
(73.2 \%)\end{array}$ & $\begin{array}{l}115 / 148 \\
(77.7 \%)\end{array}$ & $\begin{array}{l}\text { OR } 1.02 \\
(0.61 \text { to } \\
1.69)\end{array}$ & $\begin{array}{l}3 \text { more } \\
\text { per } \\
1,000 \\
\text { (from } 97 \\
\text { fewer to } \\
78 \\
\text { more) }\end{array}$ \\
\hline \multicolumn{11}{|c|}{ Secondary Bacteraemia } \\
\hline 3 & $\begin{array}{l}\text { observational } \\
\text { studies }\end{array}$ & $\begin{array}{l}\text { serious } \\
\mathrm{h}\end{array}$ & not serious $^{i}$ & not serious & not serious & $\begin{array}{l}\text { strong } \\
\text { association }\end{array}$ & $\begin{array}{l}78 / 254 \\
(30.7 \%)\end{array}$ & $\begin{array}{l}64 / 558 \\
(11.5 \%)\end{array}$ & $\begin{array}{l}\text { OR } 2.75 \\
(1.86 \text { to } \\
4.06)\end{array}$ & $\begin{array}{l}148 \\
\text { more per } \\
1,000 \\
\text { (from } 79 \\
\text { more to } \\
230 \\
\text { more) }\end{array}$ \\
\hline \multicolumn{11}{|c|}{ Secondary Pneumonia or superinfection } \\
\hline 4 & $\begin{array}{l}\text { observational } \\
\text { studies }\end{array}$ & $\begin{array}{l}\text { serious } \\
\mathrm{h}\end{array}$ & serious $^{f}$ & not serious & not serious & $\begin{array}{l}\text { strong } \\
\text { association }\end{array}$ & $\begin{array}{l}70 / 282 \\
(24.8 \%)\end{array}$ & $\begin{array}{l}45 / 581 \\
(7.7 \%)\end{array}$ & $\begin{array}{l}\text { OR } 2.93 \\
(1.92 \text { to } \\
4.46)\end{array}$ & $\begin{array}{l}120 \\
\text { more per } \\
1,000 \\
\text { (from } 61 \\
\text { more to } \\
195 \\
\text { more) }\end{array}$ \\
\hline
\end{tabular}

Cl: Confidence interval; OR: Odds ratio; HR: Hazard Ratio

\section{Explanations}

1. The overall risk of bias was assessed as moderate due to confounding factors. Due to the imbalance of confounders, the results favored the control group. 
2. High heterogeneity as I2>50\%. Sensitivity analysis with the removal of Sanz et al and Capra et al have decrease heterogeneity to $14 \%$ with a statistically significant decrease in mortality with tocilizumab.

3. As the confidence interval of pooled effect estimate includes 1, Hence, downgraded for imprecision.

4. As the confounders were adjusted so as to calculate adjusted HR, the confounders can't have effect on the pooled effect estimate. Hence, overall ROB for adjusted HR for mortality was assessed as low.

5. $12=74 \%$, which showed an increase heterogeneity. However, as all the studies after adjustment of covariates had shown to decrease mortality with tocilizumab, heterogeneity was ignored. Hence, not downgraded for inconsistency.

6. As $12>50 \%$, hence downgraded for inconsistency.

7. As the confidence interval of the pooled effect estimate includes 1. In addition, Overall information size (OIS) of 188 was not achieved. Hence, downgraded for imprecision.

8. The overall ROB was assessed as moderate or serious for the included studies. Hence downgraded for ROB.

9. $12>50 \%$. As all studies have observed an increased risk of secondary bacteremia, heterogeneity was ignored.

\section{Figures}
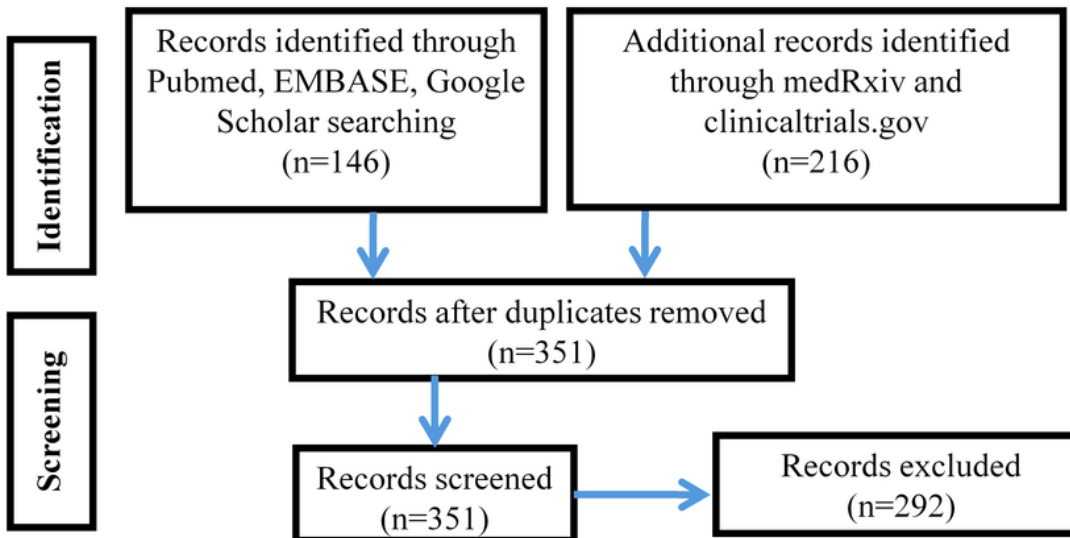

Records after duplicates removed

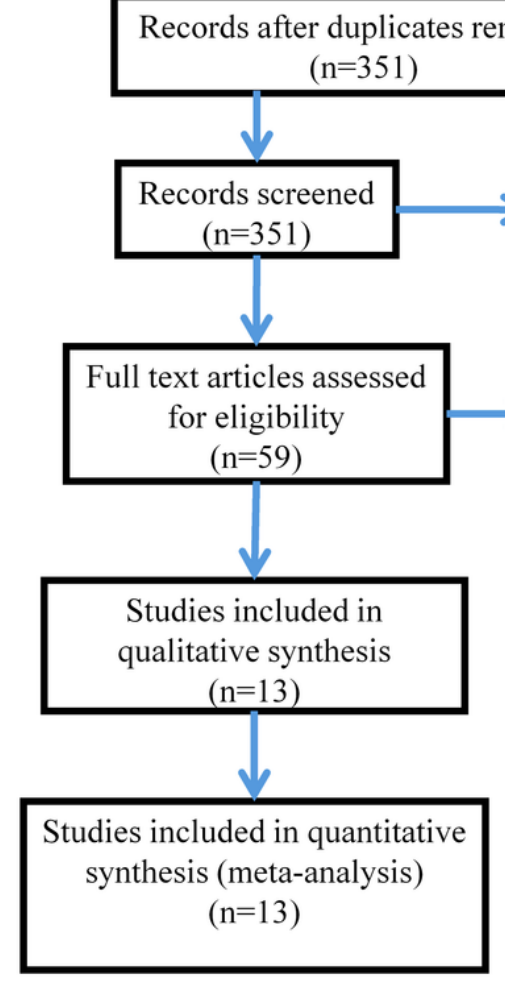

Figure 1

PRISMA flow chart depicting study selection process 


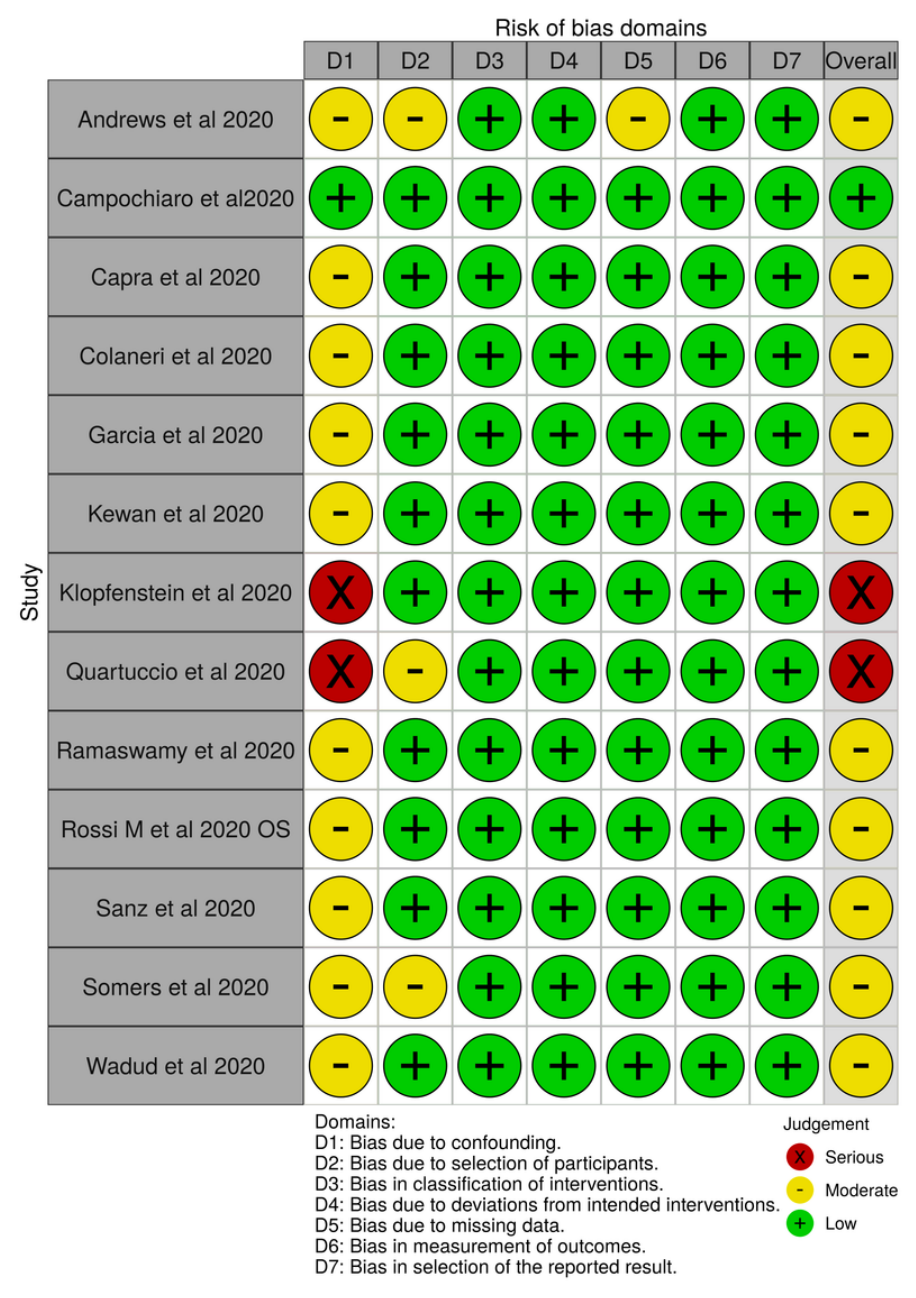

\section{Figure 2}

ROBINS-I: Risk of bias in observational studies evaluating tocilizumab in the treatment of COVID-19 
Tocilizumab Control

Odds Ratio

Odds Ratio

Study or Subgroup

Events Total Events Total Weight M-H, Fixed, $95 \% \mathrm{Cl}$

$\mathrm{M}$-H, Fixed, $95 \% \mathrm{Cl}$

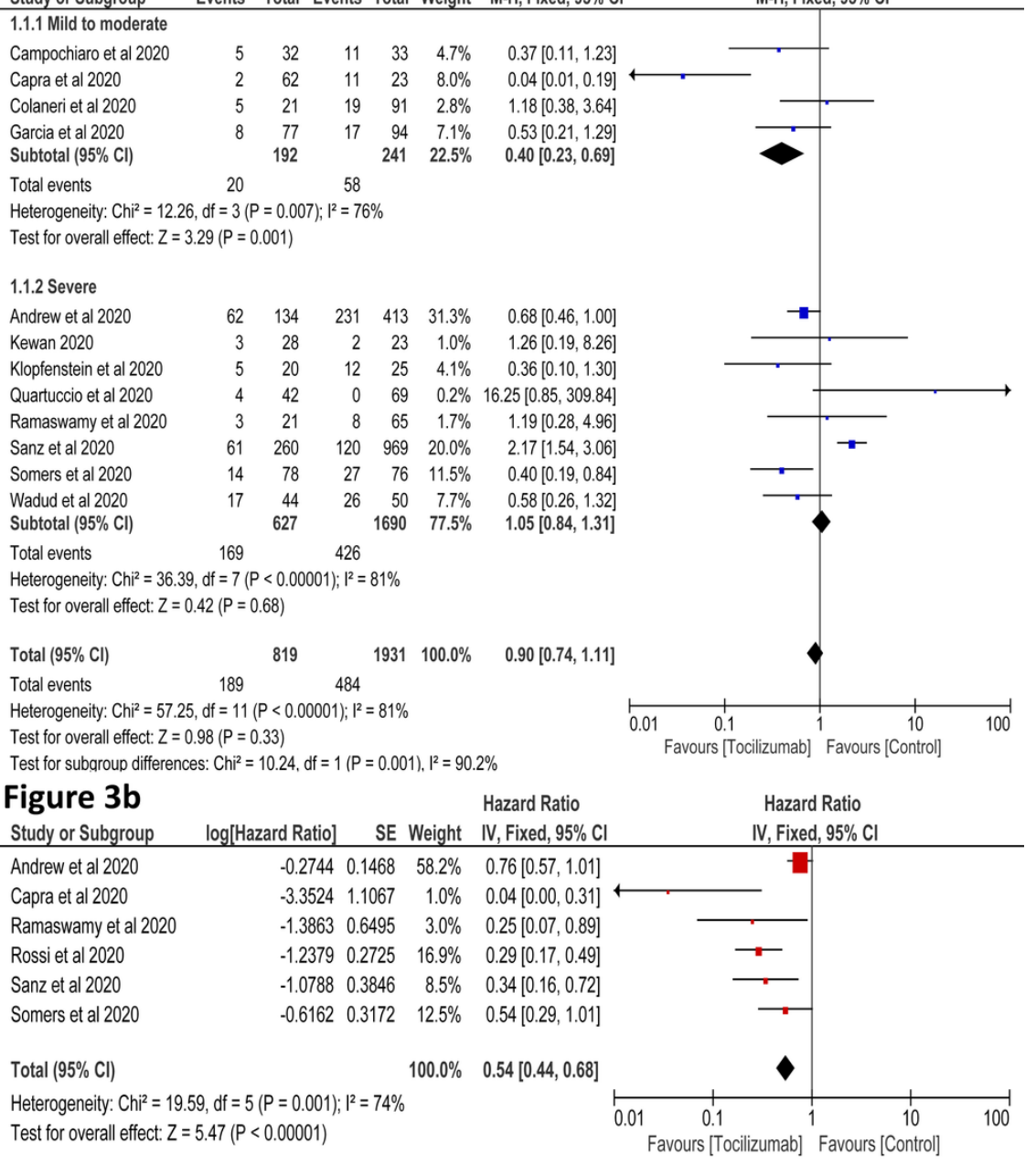

Figure 3

Mortality rate (unadjusted-3a)(adjusted-3b) of tocilizumab vs control treatment

Tocilizumab Control Odds Ratio

Study or Subgroup

Events Total Events Total Weight M-H, Fixed, $95 \% \mathrm{Cl}$

Campochiaro et al 2020

Capra et al 2020

Colaneri et al 2020

Garcia et al 2020

Klopfenstein et al 2020

Total $(95 \% \mathrm{Cl})$

Total events

Heterogeneity: $\mathrm{Chi}^{2}=16.83, \mathrm{df}=4(\mathrm{P}=0.002) ; 1^{2}=76 \%$

Test for overall effect: $Z=4.39(P<0.0001)$
Odds Ratio

M-H, Fixed, $95 \% \mathrm{Cl}$

\section{Figure 4}

Number of patients showing evidence of disease progression of tocilizumab vs control treatment 


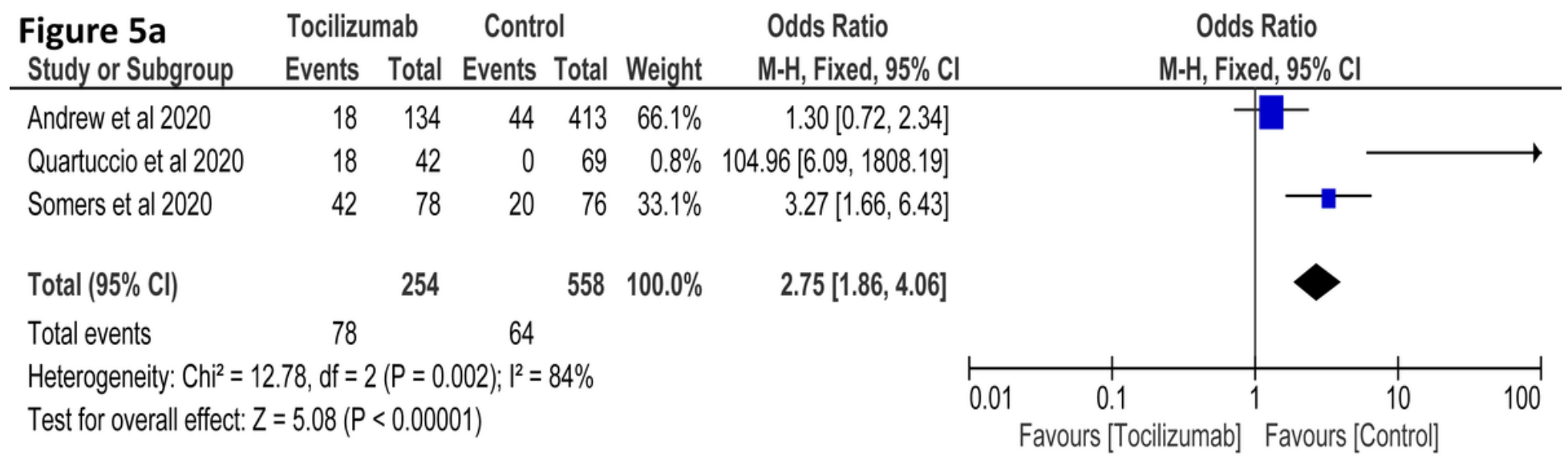

\section{Figure 5b}

Tocilizumab Control Odds Ratio

Study or Subgroup Events Total Events Total Weight
M-H, Fixed, $95 \% \mathrm{Cl}$

$1.53[0.74,3.13]$

$0.78[0.20,3.13]$

$04.96[6.09,1808.19]$

$3.31[1.61,6.80]$

$2.93[1.92,4.46]$ 45

Total events 70

$581100.0 \%$

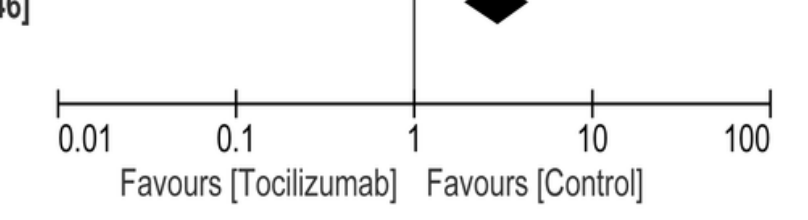

Figure 5

Number of patients with secondary bacteraemia (5a) and secondary pneumonia (5b) (tocilizumab vs control treatment)

\section{Supplementary Files}

This is a list of supplementary files associated with this preprint. Click to download.

- PRISMAchecklistTocilizumab.doc

- OnlineFigure1SROBINSI.Png

- OnlineFigure2S.Png

- OnlineFigure3S.Png

- OnlineFigure4S.Png 